\title{
Adenocarcinoma In Situ in Adenomatous Polyp
}

National Cancer Institute

\section{Source}

National Cancer Institute. Adenocarcinoma In Situ in Adenomatous Polyp. NCI

Thesaurus. Code C7678.

A non-invasive adenocarcinoma arising from the neoplastic glandular cells in an adenomatous polyp. 